\title{
In Their Own Voices: Contemporary \\ Native Hawaiian and Archaeological \\ Narratives about Hawaiian Archaeology
}

Kathleen Kawelu

\begin{abstract}
A global discussion about the colonial roots of research and non-Western peoples has developed over several decades (Asad I973; Said I978; Mihesuah 1998; Smith 2005). Pacific Islands people have contributed to this conversation, calling for greater indigenous involvement (Allen and others 2002; Baba and others 2004; Bishop 1998; Smith 1999). Growing voices, particularly of indigenous scholars, advocate decolonizing the academy (Bruchac and others 2010; Mihesuah and Wilson 2004; Smith and Jackson 2006; Smith and Wobst 2005). Within archaeology, this can involve increasing collaboration with descendant communities, training indigenous people in archaeology, responding to reburial and repatriation issues, and revising ethics principles (Atalay 20I2; Greer and others 2002). Native Hawaiians are also addressing nearly two centuries of colonialism and critiquing archaeology in Hawai'i since the I97os. The reluctance of archaeologists to acknowledge the "politics of the past"-such as the dominance of archaeologists in constructing and telling the past, and the need for practical applications of archaeologically produced knowledge for descendant communities - continues to be challenged (Trask I999b). Until recently, too few archaeologists proactively called for collaborative engagement with descendant communities; thus, these relationships have been characterized by tension (Cachola-Abad and Ayau I999).

The purpose of this article is to examine the relationships between archaeologists and Native Hawaiians, which are strongly influenced by past events, and to move beyond anecdotal understandings by document-
\end{abstract}

The Contemporary Pacific, Volume 26, Number I, 3 I-62

(C) 2014 by University of Hawai'i Press 
ing the views of individuals from both groups through in-depth interviews (Kawelu 2007). Comprehending the views of each group is essential to addressing long-standing frictions between them, which in turn have an impact on the preservation and management of Native Hawaiian cultural remains. Ultimately the relationships between these stakeholders affect the degree to which Native Hawaiian culture is perpetuated. This research was prompted by Native Hawaiian concerns voiced to me about the practice of archaeology in the islands and by my desire to incorporate this perspective, which has largely been absent, into the practice of Hawaiian archaeology.

The tensions in archaeology between Native Hawaiians and archaeologists stem from the colonial history of the islands (Kame'eleihiwa I992; Osorio 2002; Silva 2004; Trask 1999a), as well as from the history of archaeology. These histories form the backdrop against which the narratives presented in this article play out. While a comprehensive discussion of these histories is not possible here, a brief outline may be helpful. Significant external attempts to alter Hawaiian culture began with missionization in $\mathrm{I} 820$. Increasing incorporation into a larger world system contributed to devastating population losses caused by introduced diseases, the adoption of private landownership in the mid-I80os, and the illegal overthrow of the Hawaiian kingdom in 1893 . Struggles for sovereignty persisted throughout the twentieth century, with efforts in areas like music, voyaging, hula, and language revitalization swelling in the Hawaiian Renaissance of the I970s (Kanahele I982). Explicit calls for political sovereignty gained momentum in the I980s, prompting both a 1993 apology from the United States for its role in the overthrow of the Hawaiian nation and congressional attempts to initiate a process for federal recognition of a Native Hawaiian governing entity throughout the first decade of the twenty-first century. It is within this context that archaeology developed in the islands.

The history of Hawaiian archaeology began with the founding of the Bernice Pauahi Bishop Museum in I889. In I920, the museum and the University of Hawai'i formally partnered to promote scientific research and to facilitate student training. These institutions dominated Hawaiian archaeology into the I970s, when few archaeologists practiced in the islands, and projects were almost exclusively research driven. This institutional monopoly and stimulus for archaeological work changed in the I970s, stemming from statehood, which introduced federal monies and laws associated with economic development and historic preservation 
(Kirch 2000). The first state legislation involving heritage management authorized a statewide inventory of historical and cultural sites through the Division of State Parks in 1967. Today, the State Historic Preservation Division (SHPD), which separated from State Parks in I990, is the primary heritage management agency in Hawai'i. The Historic Preservation Division's responsibility, which dominates staff time, is regulating activities that affect historic and cultural properties. Governmental monitoring is primarily done by reviewing reports produced by private archaeological firms that have been contracted by landowners and developers. The work of these private contract archaeology firms, which now prefer to be called cultural resource management (CRM) firms, and the SHPD review of their reports, encompasses the vast majority of archaeological work carried out in Hawai'i today, as is the case elsewhere in the United States. The hiring of these firms by developers is viewed by many in the public as a conflict of interest between historic preservation and land development; consequently, the work of CRM firms is heavily scrutinized.

The formalization of Hawai'i's historic preservation office in I990 coincided with the development of the state's burial laws. Construction of a hotel on a known Hawaiian burial ground at Honokahua, Maui, in the late I980s unearthed over a thousand human remains, sparking the demand for burial laws. Prior to I990, individuals buried in unmarked graves were not given the same protection under state and federal laws as those in formal cemeteries. Thus their disinterment was allowed to take place under Department of Health and county permits. The legacy of Honokahua is the Burial Sites Program and its five Island Burial Councils, composed of Native Hawaiians and large property owners, which oversee the treatment of previously identified remains affected by land development. The burial councils have the ability to recommend how previously known burials should be treated, which is usually accepted by the state archaeologists. However, Island Burial Councils do not have jurisdiction over inadvertently found burials, which were not identified by descendants or private archaeological firms prior to accidental disturbance. Historic preservation laws mandated archaeological consultation with Native Hawaiians, but earlier anthropologists had often worked with Native Hawaiians prior to the enactment of those laws.

In the first half of the I900s, anthropologists obtained knowledge of the culture from years of interaction with Hawaiian descendants, but later archaeologists would come to rely less on interpersonal relationships and more on the written documents produced by other anthropologists. This 
trend reflected a decrease in native participation, fostered by increased reliance on excavation at the expense of oral histories; a focus on general laws of human behavior rather than on in-depth understandings of particular places and people; and an increase in compliance-driven archaeology, with its budgetary and time constraints and emphasis on satisfying legal mandates rather than community needs. Just as the Hawaiian Renaissance was gaining momentum in the r970s, the practice of archaeology was changing significantly, in a direction that did not match the values of that cultural movement. This divergence had an impact on relations between archaeologists and Native Hawaiians for decades.

As a Native Hawaiian practicing archaeology, I chose to focus my research on the relationships between Native Hawaiian and archaeological communities because of my own struggle to participate in a discipline that many in my community criticize. My research fits into a broader movement of indigenous archaeology, which seeks to empower indigenous peoples by negotiating a path between indigenous and archaeological values and responsibilities (Colwell-Chanthaphonh and Ferguson 2008; Silliman 2008; Watkins 2000). In 2005, I interviewed twenty-seven individuals with strong ties to Hawaiian culture, archaeological practice, or both. Their stories emphasize lived experiences and perspectives on Hawaiian archaeology. This article presents the attitudes of Native Hawaiians and archaeologists toward archaeology and each other, documented in audiotaped interviews, with the goal of finding common ground between the groups.

I spoke to individuals on five islands, including Native Hawaiians engaged in varying levels of political activism. Native Hawaiians who identify as activists and those who do not identify as such are designated by different identifiers ( $\mathrm{NH}$ actv, NH). Archaeologists are identified by occupation, including academic (acad), cultural resource management (CRM), and government or public sector work (govt). Native Hawaiian archaeologists are identified by the letters $\mathrm{NH}$ arch. Hawaiian pseudonyms have been assigned to individuals of Native Hawaiian ancestry and English pseudonyms to non-Hawaiian individuals.

\section{Interview Groups and Subgroups}

Native Hawaiian Archaeologist or Community Member

- Activist community member ( $\mathrm{NH}$ actv)

- Non-activist community member (NH)

- Archaeologist (NH arch) 
Non-Native Hawaiian Archaeologist

Academic (acad)

Cultural Resource Management (CRM)

Government or public sector (govt)

The conversations with the people I interviewed were prompted in part by my questions, a mixture of single-response and open-ended questions that had participants recalling events and situations that fostered current circumstances and personal perspectives regarding Hawaiian archaeology. Some interview questions more than others evoked narrative responses, such as "How would you describe the relationships between Hawaiians and archaeologists? Are there specific events or circumstances you believe led to these relationships?" The responses often included spontaneous storytelling, particularly when the interviewees provided examples of their own experiences in Hawaiian archaeology. Using narrative analysis, which seeks to understand how speakers make sense of the world by analyzing their narratives, I identified relevant texts and ideas emphasized by the speakers, and I grouped repeating ideas into larger themes. These themes, as told through stories, reveal common values and perspectives of the speakers.

Two broad narratives surfaced during interviews, which represent the perspectives of eleven Native Hawaiians, eleven archaeologists, and five Native Hawaiian archaeologists. The first narrative concerns a growing Native Hawaiian voice, insisting that archaeologists recognize a living Hawaiian culture that is relevant to archaeological practice. This broad narrative, under the heading "Taking the Lead," weaves together four different stories of the persistence of Hawaiian cultural beliefs and practices. In this living-culture narrative, individuals spoke of cultural responsibilities, the incongruence between some traditional cultural practices and current heritage laws, judgment of our actions by forces greater than those in the judicial system, and increasing involvement of Native Hawaiians in archaeology.

Concerning the discipline of archaeology and its practitioners, the second narrative, "Evaluating Archaeologists," describes a range of archaeological commitment to understanding the Hawaiian past and to engaging Hawaiian descendants. In this characterization, there are four levels. At the bottom are archaeologists who prioritize profit and appear to lack any professional or community investment. Occupying the next two levels are archaeologists who exhibit a degree of commitment to the discipline 
broadly and those invested specifically in Hawaiian Culture and Hawaiian archaeology. On the final level are the increasing numbers of archaeologists who seek a degree of commitment that honors the people whose past we study, as well as their descendants. Native Hawaiians minimally desire this degree of archaeological investment. While the organization of these narratives is mine, the interviewees' voices are central, and their words are presented for the reader to hear. ${ }^{1}$

TAKING THE LEAD

"We're a Living Culture"

Contemporary Native Hawaiians are part of a living culture that, like any culture, involves a dialectic between continuity and change (McGregor 2007). As Maile ( $\mathrm{NH}$ ) explained, "We don't do things exactly that way anymore because we have evolved from that, but it doesn't mean we're not a living culture." Some, like Abby (govt), said, "I should be willing to accept that culture can change and people can change with culture, and that's okay too, but I think there needs to be a clear recognition of what really is the past and what people really did, versus this is how we are now and this is where we're going." However, many archaeologists studying our culture perceive a disconnect between who we were and who we are, questioning the knowledge and concerns of living Native Hawaiians.

Individuals like Maile (NH) spoke of a time when "previous generations were made to feel like what they had wasn't worth anything." Even within archaeology, Ikaika (NH) recalled that in the I960s, "I was on the dig, I was a Native Hawaiian, [and the archaeologist said,] 'Ah, you're nothing.' . . . I'm there just as a workman." Such disregard contributed to silencing Native Hawaiians within the land development process. Matt (CRM) related that in the I970s, "I don't know if the Hawaiians weren't interested, [but] there was no space for them. Developers weren't interested in listening to them." Neither were government officials, specifically during the I980s Ritz-Carlton Hotel controversy, when, Hoku (NH actv) remembered, "The [Maui] Planning Commission made that determination [to grant building permits on a known burial site], and it rings in my ear, this Japanese commissioner from Moloka'i say, 'Eh, you know what, no matter what you Hawaiians say we going give the permit, and I gotta catch one plane at four o'clock." The treatment of human remains is still central to Native Hawaiian concerns with the discipline, as Kawika ( $\mathrm{NH}$ 
actv) continued: "That's where everything really went downhill. When they started treating the bones the same way they were treating them for the last fifty years. Not knowing that the living culture, they change, right. Maybe fifty years ago nobody cared about the bones, but now everybody cares. So the archaeologists gotta know that they gotta change." A clear call for action and recognition of a vibrant living culture has been made, but regardless of whether this recognition is given, Hawaiian cultural practices persist.

\section{"Hawaiians, They Very Clear on Kuleana"}

For much of the nineteenth century, Hawaiian culture was attacked as immoral and uncivilized, encouraging Native Hawaiians to feel ashamed of being Hawaiian. Despite this stigma, which by the first half of the twentieth century had become ingrained, some families kept cultural knowledge alive. Nani (NH) said, "When it wasn't fashionable to be Hawaiian, my mother kept it: the language, the culture. My mother was a feather master." Wahine ( $\mathrm{NH}$ ) learned to fish: "Also we go up mahi'ai [cultivate] our garden up in Wailau [Ka'ū]." Others like Ulu (NH actv) know "stories about people who take care of capes, bones, family stuff, where they take care of them in certain secluded areas on this island [Hawai'i]." For some, this knowledge negates the need for archaeological inquiry. Hi'ilei ( $\mathrm{NH}$ arch) opined, "It's not generally a field of study that somehow Hawaiians got involved with because maybe they just felt it wasn't that important because their culture was still around. If you're living your culture, why do you need to kind of look at it from a formal aspect?" Sam (CRM) was told by one Native Hawaiian, “A lot of Hawaiians don't want to hear what the archaeologists have to say about their culture because they know their culture and they know where they're from. Again, most archaeologists aren't from Hawai'i, or even Hawaiian. I mean there's even less Hawaiian archaeologists than people from Hawai'i. So he told me flat out, he goes, a lot of people didn't want to hear what you have to say."

The perception that archaeology is unnecessary for understanding Hawaiian culture is grounded in the confidence of cultural knowledge, but kuleana (responsibility, right) is a factor as well. Briefly, kuleana are responsibilities associated with things like family, homeland, and expertise. My obligation is to care for my kuleana, while not interfering with the kuleana of others. Describing family involvement in claiming human remains, Ikaika $(\mathrm{NH})$ insisted, "Hawaiians, they very clear on kuleana. If this is their kuleana, fine. If they not their kuleana, eh, they don't get 
involved with that because to lay claim to somebody else's bones is a no-no."

Native Hawaiians see archaeologists as involving themselves in matters that do not concern them-a breach of kuleana because most archaeologists are not working on the remains or lands of their own communities. Any individual, Native Hawaiian or not, getting involved in another person's kuleana is considered maha'oi (presumptuous) or nīele (nosy), as Aolani ( $\mathrm{NH}$ arch) was taught as a youth: "They're always like, don't maha'oi, don't go over there, that's not your kuleana." Even Ikaika (NH), who views archaeology mostly in a positive light, admitted, "Of course there is the other part of archaeology that we Hawaiians react to, and that's the negative part because they're exposing ... those things shouldn't be out in the open." Sam (CRM) recalled a Native Hawaiian archaeologist being unable to secure an interview with a Maui kupuna (elder) because she was from Moloka'i. He offered, "Some people won't talk to you because you're not from the same island. . . . It's like, well, you may be Hawaiian, but you're not from Maui, I'm not talking to you. You're not from Moloka'i, I'm not talking to you. So if you have that division among Hawaiians, of course, coming in as a haole [Caucasian] guy or Japanese guy whatever, you're going to have that. Of course, if they don't look at other Hawaiians the same way, of course they're not going to accept you."

This philosophy of kuleana permeates all aspects of Native Hawaiian culture and contributes to some of the friction with archaeology, particularly involving human remains. Ulu (NH actv) affirmed, "Our iwi [bones] matter because they are our people; they're like taking care of our kūpuna [elders]. 'Oia wale nō [It is just that] we don't take care of our kūpuna, then what?" Maintaining burial sites is also crucial to many Native Hawaiians, and thus relocation is rejected. While new burial laws have helped to a certain degree, land development and cultural integrity are often pitted against one another, as Puna (NH actv) recognized: "Nobody's going to stop a Walmart because they found a few ancient bones." Native Hawaiians are left to choose between the lesser of two evils, as in the scenario Nani (NH) described: "Do you want your kūpuna [elders] staying close to a sewer line, in a driveway? Do you want this, or would you rather them just move them over, same area, not far away, and put a garden so they always safe?" Ikaika $(\mathrm{NH})$ voiced his discontent with his own experiences: "I was very angry, and the point I was saying that, why do they treat our Hawaiian burial sites not like modern-day cemeteries? Because these are human beings, and these are their burial grounds." The discrepancy in 
treatment of marked and unmarked burials (most precontact Hawaiian burials being unmarked) leaves Native Hawaiians aggravated.

A lack of communication about historic preservation laws and the discipline has led many Native Hawaiians like Ulu ( $\mathrm{NH}$ actv) to believe, "It's all bones to me. Archaeology, don't you just usually find bones, kind of thing?" For Native Hawaiians, the purposeful disturbance of human remains is disrespectful, and osteology (the scientific study of bones), which some Native Hawaiians associate with craniological studies of the I 800 s, involves further disrespect. Recounting her repatriation efforts on the East Coast in I990, Onaona ( $\mathrm{NH}$ ) explained these "skull wars" (Thomas 2000): "They wanted skulls so that they could measure them and see if the size of the cranium equaled their intelligence." Ultimately, Ulu (NH actv) demanded, "They need to stop digging us up, they need to stop crushing us, they need to stop doing DNA analysis of our bones, they need to stop." Osteology, on the other hand, is not opposed by everyone. Onaona ( $\mathrm{NH}$ ), while discriminating in her reading of archaeological reports, wanted "to know more, but of course without DNA, 'cause I don't believe in that."

The Hawai'i Administrative Rules relating to burial sites and human remains (title I3, subtitle I3, chapter 300) reflects Native Hawaiian sensibilities and the acceptability of methods used to determine ethnicity of remains for reburial purposes. Most acceptable are methods utilizing oral histories and genealogies, but if this fails, then archaeological evidence associated with the burial is used. If cultural methods and archaeological contexts fail to establish ethnicity, then osteology is used. Osteological examinations must be authorized and are performed to establish ethnicity, to separate commingled remains, or to separate human and nonhuman remains. DNA testing is prohibited without the approval of the Department of Land and Natural Resources, and this process is initiated by a written request to perform DNA analysis. So far, despite popular belief that such studies have taken place in Hawai' $i$, no archaeological requests have been made for DNA testing, and no approvals for such testing have been granted.

\section{"Damned If You Do, Damned If You Don't"}

The kuleana of caring for material remains means keeping site and burial locations secret in order to prevent them from being harmed. Native Hawaiians possessing knowledge about sites are in a difficult position because cultural practices demand secrecy, but current historic preserva- 
tion laws provide the greatest protection when site locations are previously identified. Nalu (NH actv) said of this predicament, "It assumes that Hawaiians are going to want to come out, if they know of places, and inform the public of these sacred sites. So you put at risk those sites once you let that into the - - . But what do you do, do you not provide that information, and then cross your fingers? So Hawaiians are pretty much damned if you do, damned if you don't." Onaona (NH) leaned toward sharing information: "And I know people say we don't tell. Well, you know, I have mixed feelings about that because what if I know, I don't tell, I'm not here, and they go and disrupt them?" "They" are developers, another group involved in the historic preservation process, whose actions sometimes exacerbate difficult situations. Matt (CRM) worked on a project in which Native Hawaiians had "been burned before. They've shown, in the past, their own personal stories, they showed developers where the burials were and the developer went in and kicked the graves over and bulldozed. And they feel very, very bad about that."

Yet interviewees still saw profit as the primary objective of land developers, and historic preservation as an obstacle to that. Tim (CRM) believed that developers see archaeology as something that "costs money, it slows them down. And also not just developers, but a lot of the governmental agencies. Board of Water Supply ... the same with Highways, Boating. They see it as a drawback." Profit and expediency led some developers in past decades to simply destroy cultural properties and human remains. Ikaika $(\mathrm{NH})$ recovered Native Hawaiian remains unearthed during construction at Barbers Point, O'ahu, in the I960s. "We didn't finish because it was such a massive burial. [When] we came back the next day, the haole [Caucasian] supervisor, I guess he got frustrated because he wanted to complete the job, so he went with the [backhoe] and he dug up everything. The bones was just scattered all over the place." While egregious actions such as those described by Ikaika ( $\mathrm{NH}$ ) and Matt (CRM) are rare today due to the imposition of large fines and the seizure of construction equipment, other abuses persist. For instance, in 2005, Lopaka's ( $\mathrm{NH}$ arch) firm "did a monitoring plan for this canoe hālau [long house] ... down in Waimānalo. We got a call couple weeks ago, and they're asking us if we could write a report for monitoring the construction down there. And we were never down there. They did the construction without us monitoring. Now the state, to finish their permitting, is asking, well, where's your archaeological report? They're asking us to write one. We said, we can't write a report, we didn't do any work." 
Today individuals see a changing climate in Hawai' $i$ in which developers are more open to Native Hawaiian concerns regarding the land. This engagement is still largely driven by profit but that is colored by the realization that the financial cost of fighting communities outweighs the perceived freedom of excluding them. As Kawika ( $\mathrm{NH}$ actv) stated, on Moloka'i, "We've fought so much that the developers now have respect for the community. They know they going lose money if we keep fighting with them. And they have all these years. It's not good business practice." Though the actions of landowners and developers are not a part of archaeological practice, their decisions do have an impact on the historic preservation process. The changing attitudes are welcomed, but if these sensitized developers leave the islands, the cycle of education begins anew with the companies who replace them.

\section{"I'm Not Their Judge"}

The belief that our actions are judged by kūpuna (ancestors) persists, with their displeasure in or approval of our behavior revealed through hō'ailona (omens). Speaking about the practices of some developers, Onaona $(\mathrm{NH})$ said, "You know if others don't want to do things pono [properly], they gotta live with that kind of stuff. Well, if developers think they're going to get by with this-, I'm not their judge." Some Native Hawaiians have experienced hō'ailona when kūpuna showed appreciation for efforts to care for disturbed human remains and cultural sites. Ulu ( $\mathrm{NH}$ actv) recalled an experience at Hōkūli'a, Hawai'i Island, in 200I, which preceded the court-ordered halt to construction work that had encroached on a hill with burials: "What we experienced that night, swear to god, changed my life. We heard chanting that was unbelievable ... with the pahus [drums] and everything, it sounded like a thousand voices.... We just uē, uê, uē [cry, mourn]. . . . It was the night before [the prayer vigil], and everyone was startled, like, do you hear that, do you hear that? So significant. So these are the hō'ailona that you just, you no can help, man. It was beautiful.”

Recounting his involvement with the repatriation of remains from Honokahua, Maui, in the late I980s, Hoku (NH actv) told this story:

The last night we was going put the last four hundred [burials] in.... We just was going do our ceremony when we heard one slapping in the bay, Honokahua. Was one huge koholā, one whale. Turn over on the side and kept [slaps hands together] pa'i, slapping, slapping the waters of the bay. Then three owls, 
three owls, flew over our head. They screamed. So I wrote this song immediately, it came to me. And it says, at twelve o'clock the torches were lit, to let their spirits know where their bones were. They didn't know how to thank these men who laid their bones to rest. So they called upon the koholā to slap the waters of the bay and the owls to tell that they reunited with their bones at Honokahua.

Not all hō'ailona are good, and some Native Hawaiians believe displeased kūpuna reveal themselves as well. Onaona (NH) recalled her encounter in the I990s with a construction worker who sought her out, believing his illness was associated with improper and illegal work activities on the island of Kaua' $i$.

He said, "I'm on a job site in Hā'ena ... and there's some stuff going on that I'm not really comfortable with. ..." He said, "But before I tell you, can I tell you that I'm getting sick. ..." He said, "I've tried everything; I've gone to the doctor." I said, "Why don't you tell me what's happening on the job site? Let's start from there." He told me, he said they found them [human remains] and they put it under the house, and we poured cement over them.... It's called the Zimmerman case. [The landowner put the inadvertently found human remains] in the foundation. And that they poured a slab over it.

These narratives reveal a connection between past and present as well as Native Hawaiian desires for greater archaeological awareness of spiritual and kuleana concerns. Hoku (NH actv) explained, "I'm telling you it's really important, if you want to make an impression in Hawai'i you cannot go totally haole [Caucasian]. You gotta encompass a Hawaiian prospect, or Hawaiian values with your archaeology." Elders teach and perpetuate Hawaiian culture through daily practice, and the youth ensure a strong future.

\section{"What the New Generation Brought Was Voice"}

Native Hawaiians are shedding the burdens of colonial baggage. Matt (CRM) has seen the transformation over several decades: "It's a good thing to be Hawaiian in Hawai'i, and that's a change. Through the guilt trip part of it from the missionization, not through it but getting over that, but that confidence and just centeredness that I saw in Tonga, it's coming back and it's being rebuilt." Part of this confidence translates into assuming more responsibility for protecting our culture through awareness and vocalizing concerns. Before the I980s, archaeology was not a primary concern for most Native Hawaiians who were not involved in or aware of 
the field. Ikaika (NH) said, "For us Hawaiians, lot of these areas are new areas. So you got to give us time to learn and then to be able to then deal with the process in a more appropriate way." By expressing concerns, protesting, and participating in decision-making processes, Native Hawaiians are advocating for ourselves. Nani $(\mathrm{NH})$ recognized that "what the new generation brought was voice."

Many Native Hawaiian interviewees were critical of archaeologists who do not listen to Native Hawaiian concerns. 'Eleu (NH) said that archaeologists "keep saying you're doing this for the benefit of the [Native Hawaiian] community, but where is the benefit if the community's saying no?" Resistance is particularly strong concerning burials. Hoku ( $\mathrm{NH}$ actv) recounted that, in the I980s, "when Hawaiians from all around came to Honokahua, we had a huge protest. And then we took the protest to Honolulu. ... John Waihe'e was the governor, and we had trucks blowing their horn for hours and hours, driving around the capitol. We had hundreds of people with signs, 'Leave our bones alone.' We were up, I think, almost twelve hours trying to negotiate to stop the digging." Abby (govt) also recognized the increased participation: "Since about the mid '9os, particularly with Mōkapu but now with many other [federal] NAGPRA [Native American Graves Protection and Repatriation Act] cases as well as state-level ones, the families have come to the fore.... which is the way it should be. They should be the ones involved, and they should be making decisions."

Since 2000, a growing number of Native Hawaiians have entered the discipline, moving beyond vocalizing concerns to practicing archaeology. Most Native Hawaiian archaeologists see our work as another means of advocating for Hawaiian culture and people. Lopaka ( $\mathrm{NH}$ arch) asserted that this kind of advocacy contributes to keeping some of us in this discipline. Aolani (NH arch) concurred: "The bottom line is I feel that it's better we write about our own culture than someone else coming in." Other Native Hawaiians believe that archaeologists of Hawaiian ancestry will be more respectful of our cultural remains and bring a spiritual dimension to archaeology. Wahine (NH) pictured it like this: "If I had you folks, and get more Hawaiian coming in [to archaeology], and understand how our lifestyle, I think would be better for us." Ikaika ( $\mathrm{NH})$ hoped that "those [Native Hawaiians] going to the field are Hawaiian at heart, and therefore when they deal with archaeology it's special. . . The spiritual nature of that person gets imparted in the work that they do." Efforts are underway through an archaeological internship program for Native Hawaiians to 
foster this philosophy of combining sound archaeological practice with cultural knowledge and protocols through mentorship. This summer field school for college students is run by the nonprofit branch of Kumupa'a Cultural Resource Consultants, with grants from the Kamehameha Schools and in partnership with organizations such as the University of Hawai' $i$-Hilo and Hawai'i Community College. Within three years, twelve students have been trained on Hawai'i Island through this Wahi Küpuna Program, seven have graduated with bachelor's degrees in anthropology, four have found employment in cultural resource management firms, and one has been accepted to graduate school in applied archaeology.

Concerns of archaeologists and Native Hawaiians overlap when it comes to the protection of cultural sites, but archaeology is about more than our past; it is also a tool for contemporary social and political pursuits. Tim (CRM) observed, "Oftentimes the activists are using Hawaiian archaeology as a means of fighting, primarily development . . . using everything they can to fight it, and archaeology's a real big weapon, 'cause you're destroying my heritage.'. . . They're using Hawaiian archaeology for their own goals." Ulu (NH actv) admitted, "I know Hawaiians are going to want to slow down what we see as inevitable glossing over of the depth and beauty of this place. So if it's going to be in archaeology where we stave off that onslaught, then I say holomua [advance]." Yet Yvonne (govt) also noted that some Native Hawaiians "wanted a lot of things that went beyond the historic preservation process. The historic preservation process can't stop telescopes, can't address water issues directly, [although] there's some overlap at times. There's a lot of sovereignty issues, control over public lands. There are issues that are much bigger and broader than can be addressed through historic preservation." Even within the parameters of current historic preservation laws, the combination of Native Hawaiians' and archaeologists' efforts to care for cultural sites presents a powerful partnership. In the next section I present the second narrative that emerged from the interviews.

\section{Evaluating Archaeologists}

\section{"Each One Is to Be Judged Individually"}

The individuals I spoke with described the complexities of practicing archaeology in the Hawaiian Islands and the intricacies of relationships among people concerned with Hawai'i's past. Just as Native Hawaiian communities are not monolithic, variability exists within archaeological 
communities. While archaeologists often differentiate ourselves based on employment within academic, government, or private sectors, Hawaiian categorizations are more often based on people's actions. Nani (NH) said, "Each one is to be judged individually, that's all I can say. 'Cause when you put them all in and say, 'What do you think of archaeologists, are they all kaput or not?' No, you can't do that." The narratives in this section characterize the discipline as having varied levels of commitment to Hawaiian archaeology, Native Hawaiian culture, and Native Hawaiian descendants. Archaeological commitment is described as ranging from a complete lack of consideration for the field to a deep interest in both the discipline and the Native Hawaiian past. Leadership within Hawaiian archaeology also enters the narrative, affecting the practice of the discipline and how it is perceived. Ultimately, Native Hawaiians want further commitment from archaeologists through meaningful engagement, something we are now increasingly able to find. While everyone should be judged individually, archaeologists are often lumped all together and sometimes with other groups such as land developers.

\section{"A Bus Stop to Development"}

Archaeology has changed over the last sixty years. As John (acad) stated, "The majority of archaeological work that's being done today in a place like Hawai'i, while it may subscribe to those general goals [of advancing knowledge,] the direct reasons it's being done is not because of those general goals. It's because of certain legislative or regulatory requirements that archaeology be done." Academic research is no longer the primary motive, as Eileen (govt) communicated: "The majority of the archaeology in Hawai' $i$ is done because of development and because of the federal laws and state laws that mandate that you need an archaeologist there." While archaeologists acknowledge this connection to development, although it is a legally mandated relationship, some resist the association; as Lance (CRM) expressed it: "I always feel uncomfortable, no matter who I work with. We represent developers. They pay us, and we try our best to be independent evaluators, but there's always something there." The experiences of Nalu (NH actv) led him to believe that "if you can't be cost effective, I think you can't be competitive. . . Y You have to show that you're going to be able to come in with that number that the developer is able and willing to agree to. I think that ties an archaeologist's hands. So while they may not enter the field with the motive of making money, they're pretty much forced to try and make it economic." 
Matt (CRM) said that he believes intellectually engaged work can result from cultural resource management; however, for "a whole mid range of firms ... the emphasis is not on thinking these things through. It's on getting a client through the historic preservation review process." Abby (govt), a state archaeologist in the I990s and into the 2000s, struggled with how to "get at these things when we know there's going to be a lot of stuff on a property, and then we hear this really minimal bid has been accepted for work-[a bid] that we know is not going to be adequate, in terms of even identifying all the sites, let alone dealing with them appropriately." Kawika (NH actv) depicted a troubling scenario from a community vantage point, when archaeologists "come during winter time, when all the grass is tall. They take 2,000 acres, and they take three days, and they come up with a report. . . . I mean that's out and out scamming. Just taking their money and heading on. Any fool can see that they did a horrible job." In all likelihood this scenario would result in the rejection of such a report by government archaeologists; however, this perception does reveal community distrust and cynicism toward the discipline.

The emphasis on compliance-driven archaeology has led many Native Hawaiians to negatively associate archaeology with development and the loss of land. While archaeologists make statements about a few uncommitted individuals and companies doing cultural resource management, most Native Hawaiians don't make such distinctions. Kalei ( $\mathrm{NH}$ arch) lamented this lack of investment: "There are folks that are in there doing it as their bread and butter. Slam dunk, mow, blow, and go. I think that's a negative on the profession. It becomes a business." Puna (NH actv) concurred: "All they care about is that they get to do their work, and they get big bucks." Unfortunately the actions of a few led people like Ulu (NH actv) to conclude that "they're just a bus stop to development."

Based on the actions of some profit-driven archaeologists, individuals in Native Hawaiian communities criticize all archaeologists as being selfinterested profiteers. Accusations of payoffs by developers and landowners are made, along with unflattering characterizations like those of Puna ( $\mathrm{NH}$ actv), who asserted that archaeologists "take money from anybody, and service anybody. ... Archaeologists are pimps, they are whoring for money, and that's why we hate them." 'Eleu $(\mathrm{NH})$ recalls his entry into the government oversight of historic preservation in the early I990s: "People said, so-and-so firm, best archaeology money can buy. I said, 'What does that mean?' They said, 'They can justify anything. You can have a cultural 
site there that's very significant, and they could justify mitigating it, so the project can proceed.' From the business perspective, those are the guys who are going to get the contracts."

While most archaeologists are invested in the discipline, some are not invested in Hawaiian culture. Matt (CRM) explained, "Quite a few [archaeologists] are not interested in the Hawaiian past in any meaningful way." Few archaeologists worked in the islands before the late I970s, but consulting work subsequently brought many archaeologists. Principal investigators and supervisors establish roots, but many crewmembers work in Hawai'i for a few years, then leave; their investment encompasses practicing sound science, but it does not extend to understanding Native Hawaiian or local culture. These archaeologists possess the technical skills to competently survey, excavate, or monitor cultural remains, but they lack knowledge of the native culture in which they operate, limiting their ability to make good interpretations and evaluate the significance of cultural sites. Matt (CRM) contended, "A number of firms here do very, very well, cycling these young folk through for a year, maybe two years, maybe three years, and then letting them go out the door when they become disaffected. And they never get to the point where they really know what's going on. ... In my opinion, they don't get to the point where they can, in the field, recognize when they've found something interesting."

A transitory workforce significantly hampers relationships between archaeologists and Native Hawaiian communities. Kawika ( $\mathrm{NH}$ actv) did not know of any archaeologists living on Moloka'i Island. Instead he saw that "they jump all over the place, so I don't know if they understand where they are. . . . I don't know if they have the time to understand whose culture they're digging up and what they should and shouldn't do. Because what they're digging up is not all dead and gone. So what they're doing has effects on the people, on the culture." The disconnect between practicing sound archaeology and knowing the cultural context, as well as the capitalist framework on which much Hawaiian archaeology operates, affects both native and archaeological communities.

To address concerns about investment, since the turn of the century a growing number of archaeologists have made efforts to build relationships with communities. This includes training local archaeologists, working with nonprofits to care for cultural sites and areas, and collaborating on historic preservation efforts. Archaeologists who combine disciplinary knowledge with established community ties alleviate some of the problems that have plagued archaeology in Hawai'i since the r970s. This increased 
effort stems, in part, from improved institutional leadership, which fluctuated since the late r 980 s.

\section{"Somebody Needs to Take a Leadership Role and Step Up"}

Leadership within Hawaiian archaeology is another level of investment that interviewees discussed. Hawaiian archaeology in the I960s and I970s was robust, engaging archaeologists who were genuinely interested in Hawaiian culture. Tim (CRM) recalled archaeology being the topic of "conversations at lunches and beers after work. It was, 'Have you read this and what about this?" This intellectual rigor continues today in the work of archaeologists who are invested in the Hawaiian past, including many who are operating within the parameters of CRM work. Such archaeologists see the discipline as a source of knowledge on the past, in addition to oral histories and other traditional cultural forms. Richard (acad) explained, "What archaeology does and historical linguistics does, what comparative ethnology does, what all of these things do is expand, round out, and deepen that information." These archaeologists envision their pursuits as producing knowledge that anyone can use. Kalei $(\mathrm{NH}$ arch) insisted, "Knowledge is power, and when you empower people by providing them with good, scientific, sound knowledge, that's a benefit. It's a benefit to everybody." However, fluctuations in the strength of key archaeological institutions in the islands have affected their capacity for supporting a healthy discipline.

In 1997, archaeologists gathered on Kaua'i for the annual Society for Hawaiian Archaeology conference. Patrick Kirch, the keynote speaker, discussed the development of Hawaiian archaeology and the role of key institutions in its trajectory (Kirch 1999). His speech generated much debate because of its characterization of academic institutions in particular (Cachola-Abad and Ayau I999; Cordy 1999; Griffin 1999). Today, discussion continues regarding the ability of long-standing institutions such as the Bernice Pauahi Bishop Museum, the State Historic Preservation Division, and the University of Hawai' $\mathrm{i}-\mathrm{Ma}$ anoa to guide the discipline.

For nearly one hundred years, the Bishop Museum drove Hawaiian archaeology, but the museum's oversight of the $\mathrm{H}-3$ Freeway project in the I980s, which pitted Native Hawaiians against museum archaeologists, damaged its credibility. Kalei (NH arch) said, "When you look back at the Bishop Museum, in its heyday, it was like the premier research institution. And they went on their massive purge a while back [staff firings in the I980s-I990s], and their entire professional and academic reputation is 
just sucking vegetables somewhere down at the bottom of the gutter. It's really unfortunate." Previously, Kawika (NH actv) believed that "archaeologists were either part of Bishop Museum, which had credibility, or DLNR [Department of Land and Natural Resources], which had credibility back then. "Cause they were neutral parties. So we felt that the archaeologists were there to protect our interests." That belief has changed. The museum's professional reputation suffered when the research program was redirected toward profit making via CRM projects in the I980s. Hi'ilei ( $\mathrm{NH}$ arch), formerly with the museum, conceded that " $\mathrm{H}-3$ [the controversial freeway development project on $\mathrm{O}^{\prime} \mathrm{ahu}$ ] really did us in." Charges of cultural insensitivity hurt Bishop Museum's credibility with Native Hawaiians too. Hoku ( $\mathrm{NH}$ actv) spoke of one archaeologist, "I have no respect for him.... He stuck his hand in the akua kā'ai [sennit container for human remains] and took out some objects that was at the Bishop Museum.... But who gave him the right to even do that?" These elements tarnished the museum's reputation and led Richard (acad) to state, "The Bishop Museum, in my view, has become irrelevant." While renovations to Hawaiian Hall, which exhibits Hawaiian ethnographic collections, and associated temporary exhibits have worked to allay such opinions, the museum has not assumed its former status as the premier research institution for Hawaiian and Pacific culture and history.

The government agency responsible for regulating archaeological work in Hawai'i is the State Historic Preservation Division, and in 1997 Kirch recognized it as a leader in the field. However, in 2005 , Kalei ( $\mathrm{NH}$ arch) perceived, “They're imploding as we speak. That's just disastrous in terms of how you either encourage somebody to become involved responsibly in archaeology and cultural resource management here as a profession." Native Hawaiians like Onaona ( $\mathrm{NH})$ also recognized the problem: "Something's wrong with the system. It hasn't been working for a while." The Historic Preservation Division is underfunded and overworked, and archaeologists like Sam (CRM) said they were "really worried about [the departure of longtime SHPD archaeologists in the mid-200os]. . . Who's qualified to come in? And really the people that are qualified are not going to do the job for whatever the state's paying. It's become a big political nightmare in that department now."

The division's instability means that historic preservation suffers because the staff is unable to meet compliance and review obligations, and if developers or archaeologists break historic preservation laws, the division has little means to pursue violators. Under these circumstances, 
Native Hawaiians like Kawika (NH actv) came to believe that "the State of Hawai'i doesn't give a shit about Hawaiian archaeology. Because we tried. We went out there and we tried to make issues about people busting down all our sites, and nobody cared. So we had to go fight them [the developers] ourselves." Nalu (NH actv) confirmed "the inability, for whatever reason, lack of will, lack of staffing, lack of funding, probably a combination of everything. But somebody needs to take a leadership role and step up and, and that's basically why we get involved in [legal] cases, because somebody hasn't taken that role."

The inability of the Historic Preservation Division to adequately perform its duties is largely a consequence of the lack of support received from the state. Abby (govt) witnessed the dismantling of the regulatory agency firsthand in the early 2000 s and "the failure of the State, over the last ten years or more, certainly while I was at that office, to support the State Historic Preservation Office, by both making sure the management was competent but also making sure the resources were there, including fully staffing it with qualified people. It's a bipartisan failure." This situation led the National Park Service (NPS) to designate the division a "high-risk grantee" in 2010-the first designation of its kindwhich threatened the withholding of federal grants necessary to operate the division. Issues identified in the NPS Corrective Action Plan, such as reviving the Geographic Information System program and filling thirteen vacant appointments out of the nineteen total division positions, have largely been addressed (NPS 20I0). However, with review and compliance as well as efforts to meet NPS requirements consuming much of the efforts of government archaeologists, responsibilities such as outreach and education-elements that could improve community relations-are low on the priority list.

The University of Hawai'i (UH)-Mānoa Anthropology Department is another principal institution in the islands. In 2005 , the consensus on academic archaeology, according to Larry (acad), was that "very little is being done" in Hawai' $\mathrm{i}$ - a charge applied to both the museum and the university. Abby (govt) indicated that "the university archaeologists at UH, their research focus has really been out of state. ... The exception would be Michael Graves's participation in the [Kohala project] ... but otherwise they have pretty much been single-focused field schools when they've been in state." Matt (CRM) believed that "the academic guys often don't pull their weight in the field. That's an overgeneralization and there have been times-. Pat's [Kirch] made that argument out here in the past. Got a lot 
of heat for it." While everyone does not agree with Kirch's 1997 assessment of uH Mānoa's archaeological productivity in Hawai'i, most would admit that it increased subsequently, in part benefiting from Graves's work as well as the development of an applied archaeology master's program in 2007. What have bolstered academic contributions are the efforts of smaller campuses like the community colleges, the University of Hawai' $i-$ West O'ahu, and the University of Hawai'i-Hilo. These institutions continue to develop strong programs focused on Hawai'i, emphasizing community and indigenous involvement in the field (Mills 200I). While the efforts of all these academic institutions have undoubtedly increased native participation, the numbers of Native Hawaiians in decision-making positions who can affect policy are still quite limited.

The dialogue on leadership among archaeologists shows our investment in Hawaiian archaeology and desire to improve research leadership and cultural resource management regulation. However, some Native Hawaiians do not see a place for archaeology in the culture; for instance, Puna (NH actv) stated that "it needs to be completely done away with. We don't need archaeology." Many others do see archaeology's relevance to the culture. Hoku (NH actv) said, "There's gotta be archaeology. There has to be. If you not going to touch the grave at all, fine, leave it alone, don't bother it. But it's going to be impacted. There's a lot of bones that come unearthed by the wave action, or found when people are digging for pipeline, and that's when I think archaeologists gotta come in. That's important." Lopaka ( $\mathrm{NH}$ arch) noted the value of archaeology because "it's one of the disciplines that actually allows us to have a chance to help protect our culture. It's kind of like we're the last stand, the last defense, between development and our past." Beyond affirmations that the discipline can and does protect cultural sites from indiscriminant destruction, people like Ikaika (NH) also recognized archaeology's potential for "verifying a lot of these things that we in our traditions are saying."

A broader community effort including Native Hawaiians and archaeologists, rather than relying on a few institutions as in the past, is necessary in order to maintain a vibrant Hawaiian culture. Heritage management integrates all our efforts, with cultural resource management firms performing the bulk of archaeological work, government officials ensuring quality control, and academic institutions training the next generation of practitioners. These efforts are strengthened by partnerships with Native Hawaiians, who bring not only cultural knowledge and investment but also a strong advocacy for heritage management. However, engagement 
requires give and take, learning from native communities past and present, and giving back as well.

\section{Moving beyond "Cultural Voyeurism"}

Familiar with archaeologically produced knowledge, Maka'ala (NH arch) questioned, "How does it go back, how does it inform, how does it educate, how does it strengthen the community? A lot of it doesn't." Archaeologists and Native Hawaiians recognize that knowledge is power, but Native Hawaiians say that this power exists only if knowledge is put to action. If archaeologically produced knowledge is only amassed and not put to practical use, the result is not empowerment but hoarding. Maka'ala (NH arch) noted that anthropology "comes off as cultural voyeurism. Like they objectify the people and the things they study, and they just want to learn everything about it, but they're not really interested in trying to establish a real relationship with the people or the community." Puna (NH actv) declared, "I have never, never in all the years I've been dealing with both of them, archaeologists and anthropologists ... encountered anyone who thought that native people had a claim to priority." The resulting perception on the part of Native Hawaiians like Maile (NH) is that archaeologists are "just taking and taking" without considering the needs and wishes of present-day descendants.

Until the I970s, archaeologists seemed unaware of animosity toward the discipline or its practitioners. Richard (acad) said, "It never occurred to me that there was a problem" between archaeologists and Native Hawaiians. Archaeologists like Richard (acad) perceived good relationships because of close collaboration with Native Hawaiian individuals and the absence of negative encounters: "There were [Native Hawaiian] people right there [working at the Bishop Museum], and it never occurred to Kenneth [Emory, the distinguished ethnologist and archaeologist] that there was any problem relationships with Hawaiians. Young people have dreamt all this up." Other archaeologists such as John (acad) expressed uncertainty as to whether animosity existed or whether Native Hawaiians just kept quiet: "I don't know to what extent maybe the archaeologists weren't even aware, or Native Hawaiians were just not saying. And so I'm sure there probably was more resentment over burial cave kind of stuff and so on than anybody really realized." Maile $(\mathrm{NH})$ suggested that older generations of Native Hawaiians were not pleased with the actions of archaeologists and "that a lot of things that was done used to really hurt them. And they didn't do anything about it because they felt like they couldn't." 
Between the I970s and I990s, the amount of archaeological work in the islands was disproportionate to the level of community involvement in historic preservation. Consultation did increase in 2000 with amendments to the Environmental Impact Statement Law, Hawai'i Revised Statutes Chapter 343, requiring environmental assessments and statements to include cultural impact assessments for proposed development projects. However, compliance-based consultation, which can be limited to a few individuals, is not the same as community engagement. Community work advances community needs through archaeology, such as engaging and retaining students through hands-on archaeological fieldwork or helping to protect a heavily visited cultural landscape. There are several examples of long-standing collaborative and educational relationships between Native Hawaiians and archaeologists, such as the work with Wai'anae High School students on O'ahu or the Nā Pali Coast 'Ohana on Kaua'i. Since the late I990s, archaeologists from the University of Hawai'i-West O'ahu have engaged local high school and college students to teach science, local history, and survey skills that position them to obtain jobs in heritage management. On Kaua'i, the Nā Pali Coast 'Ohana works to

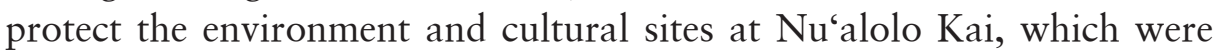
threatened by shoreline erosion, goats, and human activities. Working closely with Hawai'i State Parks archaeologists, members of the 'Ohana remove invasive vegetation, plant native flora, document cultural sites, and regularly present their work at Society for Hawaiian Archaeology meetings. Keith (govt) mentioned "examples of archaeologists working well with community groups-Nu'alolo Kai, Waipā on Kaua'i, Pi'ilani Hale [on Maui]. There's lots of examples of good, but the one that gets the most press is the bad ones "cause everybody wants to hear the bad stuff." Archaeological knowledge can benefit Native Hawaiians, if integrated into wider community goals, but sensational and controversial situations overshadow cooperative efforts and potential collaborations.

Protecting cultural sites is a shared concern, and Nalu ( $\mathrm{NH}$ actv) recognized that "there are archaeologists on Maui that have the protection of historic properties on the uppermost in their minds." Respectful treatment of human remains is paramount, and Hoku ( $\mathrm{NH}$ actv) has worked with archaeologists who "feel the iwi [bones], they feel the "uhane [spirit] at night when we kanu [bury]. They kanu, and they come with us, and they watch, and they really into it." Such respectful handling of cultural sites and remains by archaeologists is appreciated by Native Hawaiians. 'Eleu $(\mathrm{NH})$ acknowledged that “there's been some benefit. I think it 
would be irresponsible for me to say there hasn't been any benefit [from archaeology]."

However, the level of certainty that we archaeologists desire in our studies and the means by which that need is met upset many as well. Eileen (govt) perceived that archaeology "kind of fills in, I want to say gaps, but not really gaps. They have what their grandparents told them, or what they know, or what they've read in general books, but there's also gaps in the record too ... the ancient Hawaiian history, that's where archaeology comes in and fills in about that." However, many Native Hawaiians don't see gaps and find that the desire of archaeologists to obtain information clashes with native perspectives, particularly regarding the study of human remains. Ulu (NH actv) thought "archaeologists should be, well I think everybody should be epistemologists, but the idea of what constitutes as knowledge, so that they're aware that information at the price of harmony is not worth it." Nalu (NH actv) suggested, "Archaeologiststhey want to do their job the best way they think they can. That's looking for, I think, as much certainty as possible and that at times, in their mind, requires them to do as much testing as possible.... That desire on their part, while it may not necessarily in their minds be culturally insensitive, comes off that way. How much do you need to know, other than that it's a Native Hawaiian set of remains?”

The emphasis on studying Native Hawaiian sites, particularly burials, is problematic for Native Hawaiians. In the I990s, Puna ( $\mathrm{NH}$ actv) called attention to the hypocrisy, suggesting that archaeologists "go and dig up the missionary graves in the Kawaiaha'o graveyard, and [that] they look for syphilis in their skulls and their bones. They were appalled!” While osteological studies on Native Hawaiian remains were conducted into the I980s, the study of human remains today is limited to identifying individuals for repatriation and burial treatment plans. Such physical examinations of human remains are performed only if oral history and archaeological context do not otherwise provide sufficient evidence. Yet the notion persists that archaeology primarily involves burial excavation, and this perception will continue without increased communication between archaeologists and local communities.

Removing artifacts and human remains from an island, or even to a different part of an island, is another area of contention. At issue is the lack of communication about where materials are removed to, what is done with them, and whether they will be returned to their place of origin. Wahine $(\mathrm{NH})$ wondered "what they do with all those artifacts that they find." Archaeol- 
ogists also see a problem with the removal of artifacts, but for different reasons. Cultural remains are removed because there is no statewide system, including repositories on each island, for storing and curating excavated materials and records. Discussing the preservation of artifacts and primary field records, John (acad) asserted, "Millions of dollars, literally millions of dollars, are being spent every year on archaeology. But a hundred years from now, what proportion of that will actually still be in some record that Native Hawaiians, archaeologists, anybody else who cares about this past will actually have access to it? I would say it's a small percentage of what has been recovered, and that really shocks me and pisses me off." Lance (CRM) recognized that "among the community here, we have an enormous amount of collections, and there's nowhere to put it. Bishop [Museum] won't take it. It's sitting in everyone's office. It's sitting everywhere, and it's just a treasure of information. Who knows, people have thrown it out. It's probably our fault, as well as the State Historic Preservation, that we have not come to consensus on how to deal with this." The removal of artifacts and archaeologists' need for certainty are areas in which archaeologists may take from the culture without giving back. Other indicators that some practitioners are out of touch with present-day descendants include a sense of entitlement, dismissal of Native Hawaiian concerns, and a lack of communication with community members.

The investment desired by Native Hawaiians is a commitment not only to the intellectual pursuits of archaeology but also to Native Hawaiian people. Archaeologists engaged with Native Hawaiian communities are valued, showing respect for the beliefs and concerns of descendant communities. Communication is one area in which archaeologists can improve our commitment to the public, particularly in how we make our work available to interested individuals. Ikaika $(\mathrm{NH})$ offered, "Archaeologists need to talk story, and that's the part that they don't do. Talk story." 'Eleu $(\mathrm{NH})$ appreciated archaeologists who are interested in "understanding the role of requesting permission and consulting ... [and are] willing to listen." However, the level of investment in Native Hawaiian communities is not as great as it should be. Lance (CRM) has "heard countless times people stand up in front of Burial Councils or present papers. Auntie's sitting in the front row. She goes, 'I want to hear your paper 'cause that's my house. Why didn't you ever talk to me?'” Part of the problem, 'Eleu (NH) suggested, is that "you're doing this from the professional standpoint of wanting to gather information, but you're not asking anybody's permission for it." 
In other instances, communication occurs but not in a cooperative way, as in the experiences Wahine ( $\mathrm{NH}$ ) had with one archaeologist doing cultural resource management: "He's not honest with what he find. $\mathrm{He}$ always hide, he don't come out and tell us the truth." Much of the communication problem is attributed to archaeologists not including Native Hawaiians in meaningful ways; however, Ulu (NH actv) admitted, "We can do a better job to articulate what our needs are." Yvonne (govt) also lamented the lack of communication, saying, "If [Native Hawaiian organizations] had come to me with their very good ideas on how can we identify burials and require inventory surveys, fine, I would have been delighted to hear it. Instead, we get accused of colluding with the developers to avoid inventory survey so we can circumvent the Burial Councils." Sam (CRM) offered, "It's just a matter of how you approach things, and if you're honest and above board with them, it's a start."

The products of archaeological inquiries are not readily accessible either. Archaeologists like Sam (CRM) "don't think enough is done to get the information out to the public," to convey archaeologically generated information, or to explain the archaeological process, particularly in relation to land development. The inventorying, archiving, and accessing of archaeological reports produced in limited quantities for CRM work (socalled gray literature) was an issue raised in the 20 Io National Park Service report. Retrieving this literature was a concern repeatedly expressed by academic archaeologists like John (acad), who bemoaned the "problem of reports, no matter what the quality, the difficulty of getting a hold of them." If access is problematic for archaeologists, then, Lopaka (NH arch) emphasized, there is also a challenge for the public, most of whom "don't even really know where to get the material that would give them the archaeological information on something." Since 20I0, the Historic Preservation Division has worked on procedures to electronically accept and store reports, hoping to increase access. Even if members of the public successfully obtain archaeological reports, including academically generated reports, they must still contend with the language of reports. The use of specialist language (jargon), a mechanism for including or excluding people, is another means of limiting access. Kawika (NH actv) expressed his frustration: "These archaeologists were all like talking one foreign language." Again, in order for Native Hawaiians and archaeologists to build a strong partnership for heritage management, we must begin with communication and make ourselves available and open for collaborative work. 


\section{CONCLUSIONS}

Native Hawaiian communities seek an involved archaeology that recognizes the living culture, past and present. Ulu ( $\mathrm{NH}$ actv) stated, "Archaeology, fundamentally, must evolve if it's going to maintain itself as a truthseeking field. It must be filled with people more aligned with the care and concern for the perpetuation and the continuity of a culture-not simply the scientific knowledge. That separation is no longer viable, no longer synergistic with the needs of our time. One could call [it] rape, if that was not acknowledged. You can't study the history of a culture without understanding the present. People do, and I think it's part of the problem.” Native Hawaiians want to see more of an investment in the present-day community on the part of archaeologists and a willingness to be supportive and contributing members of those communities. Kawika (NH actv) spoke to this: "As archaeologists today, if you're going to be an archaeologist you cannot just be the one to go dig up and tell us this or that. You gotta be part of 'ok, now, where does this go, how does this thing stay alive, or how does it progress?' You gotta be part of a bigger picture."

The bigger picture decenters archaeology, emphasizing Native Hawaiian people and culture rather than a disciplinary approach to understanding the people. Maile $(\mathrm{NH})$ explained, "The whole idea of improving the relationship [between archaeologists and Native Hawaiians] is good and well. It's a good thing. But improving the relationship also has to do with understanding me [as a Native Hawaiian], more than understanding archaeology." This reframing does not exclude archaeology, particularly with the discipline's capacity to support efforts to protect cultural landscapes, document cultural practices, and advocate for Native Hawaiian communities. However, such collaboration is dependent on developing meaningful relationships, a point to which Wahine $(\mathrm{NH})$ commented, "If we think they're [archaeologists] going to be pono [proper], do it right, then we can converse with that and find out what their mana'o [thought] is. . . If I don't like them, I'm not going to tell you what I have." As archaeologists, our job is to hear what Native Hawaiian communities are saying; we are accustomed to focusing on voices revealed in the archaeological record, but we need to tune our ears to the voices of today's Native Hawaiians as well.

Archaeologists and Native Hawaiians I spoke to affirm the persistence of a living Hawaiian culture that incorporates the teachings of past generations in contemporary struggles. Kuleana is alive, compelling Native 
Hawaiians to vocalize disapproval of irresponsible land development and unengaged archaeological practice. Both archaeologists and Native Hawaiians condemn those who participate in the discipline for profit alone, with the vast majority of practicing archaeologists demanding greater commitment to the Hawaiian cultural past. Native Hawaiians, those who see value in archaeology, want a commitment to the people whom archaeologists study. This commitment situates archaeology within a larger framework that serves Native Hawaiian communities; by decentering the discipline, its relevance to descendant communities increases. If archaeologists look critically at the impacts of our own need for certainty and our treatment of artifacts and their removal from islands, recognize the kuleana of Native Hawaiians, and work to strengthen old and new institutions of leadership, we will take positive steps toward collaboration.

I see myself and other archaeologists moving toward a communitybased participatory research paradigm that recognizes past disciplinary shortcomings in order to change the future trajectory of stewardship in Hawai'i. Collaborative efforts to promote cultural stewardship are necessary if the discipline is to be sustainable. Such collaboration pulls together multiple knowledge systems, develops research programs from community-identified interests, benefits all involved partners, and builds community capacity. Compliance-based consultation places value on community knowledge and provides an avenue for collaboration, but more engagement is required. Yet the majority of archaeological work performed in the islands is driven by cultural resource management, and it is a challenge to sustain collaboration within the financial parameters and time frame of development-driven projects. While addressing community-identified interests is more easily achieved in academically driven archaeology, archaeologists working within cultural resource management can engage local communities through outreach and open communication, and the effort will benefit Hawaiian archaeology.

While this article presents key issues in Hawaiian archaeology important to the individuals I communicated with, it is not an endpoint. The utility of this exercise lies in creating greater awareness of needed changes in the practice of archaeology. The desire for collaboration is present; as 'Eleu (NH) put it, "Anybody can come into the Hawaiian community, regardless of what race they are, and work in the Hawaiian community if the people believe that they are genuine, that they have aloha [compassion], and they have respect for the desires of that community." 
THIS RESEARCH would not have been possible without the generous participation and cooperation of the many Native Hawaiian and archaeological community members who spoke to me. I am grateful for their willingness to share their knowledge and time. I appreciate the comments from Kale Langlas, Jennifer Kahn, and Peter Mills, as well as the input of Craig Severance and Fiona McCormack. The comments of the anonymous reviewers also helped to improve this piece, but of course all errors and shortcomings are my own responsibility. This article was made possible in part through the support of a Mellon-Hawai $i$ Postdoctoral Fellowship.

\section{Note}

I Readers familiar with the controversial cases of the past decade in Hawai'i that appear to position Native Hawaiians and archaeologists on opposing sides of the development debate, such as the Ke'eaumoku Street Walmart and Kawaiaha'o Church on O'ahu, or Naue, Kaua'i, will notice that these more recent cases are absent in the narratives. One factor is the timing of these interviews, which took place in 2005 , before some of these recent cases became a major issue. It also appears that the perspectives held by the Native Hawaiians and archaeologists I interviewed were formed by events of the distant past, while these more recent episodes serve to reinforce these perspectives.

\section{References}

Allen, Harry, Dilys Johns, Caroline Phillips, Kelvin Day, Tipene O’Brien, and Ngāti Mutunga

2002 Wāhi Ngaro (The Lost Portion): Strengthening Relationships between People and Wetlands in North Taranaki, New Zealand.

Asad, Talal, editor World Archaeology 34 (2): 3 I 5-329.

I973 Anthropology and the Colonial Encounter. London: Ithaca Press. Atalay, Sonya

20I2 Community-Based Archaeology: Research with, by, and for Indigenous and Local Communities. Berkeley: University of California Press.

Baba, Tupeni, 'Okusitino Māhina, Nuhisifa Williams, and Unaisi Nabobo-Baba, editors

2004 Researching the Pacific and Indigenous Peoples: Issues and Perspectives. Auckland: Centre for Pacific Studies, The University of Auckland. 
Bishop, Russell

I998 Freeing Ourselves from Neo-colonial Domination in Research: A Māori Approach to Creating Knowledge. International Journal of Qualitative Studies in Education I I (2): I99-2 I9.

Bruchac, Margaret M, Siobhan M Hart, and H Martin Wobst, editors

2010 Indigenous Archaeologies: A Reader on Decolonization. Walnut Creek, CA: Left Coast Press.

Cachola-Abad, C Kēhaunani, and Edward Halealoha Ayau

I999 He Pane Ho'omālamalama: Setting the Record Straight and a Second Call for Partnership. Hawaiian Archaeology 7:74-8I.

Colwell-Chanthaphonh, Chip, and T J Ferguson, editors

2008 Collaboration in Archaeological Practice: Engaging Descendant

Cordy, Ross

Communities. Lanham, MD: Alta Mira Press.

I999 Thoughts from the Chaotic Midst of Hawaiian Archaeology. Hawaiian Archaeology 7:82-88.

Greer, Shelley, Rodney Harrison, and Susan McIntyre-Tamwoy

2002 Community-Based Archaeology in Australia. World Archaeology 34

Griffin, P Bion

$$
\text { (2): } 265-287 \text {. }
$$

I999 Hawaiian Archaeology: A Post-colonial History. Hawaiian Archaeology 7:89-98.

Kame'eleihiwa, Lilikalā

I992 Native Lands and Foreign Desires: Pehea La E Pono Ai? How Shall We Live in Harmony? Honolulu: Bernice Pauahi Bishop Museum Press.

Kanahele, George S

I982 Hawaiian Renaissance. Honolulu: Project Waiaha.

Kawelu, Kathleen

2007 A Sociopolitical History of Hawaiian Archaeology: Kuleana and

Kirch, Patrick V

Commitment. PhD dissertation, University of California at Berkeley.

I999 Hawaiian Archaeology: Past, Present, and Future. Hawaiian Archaeology 7:60-72.

2000 On the Road of the Winds: An Archaeological History of the Pacific Islands before European Contact. Berkeley: University of California Press.

McGregor, Davianna P

2007 Nà Kua'āina: Living Hawaiian Culture. Honolulu: University of Hawai'i Press.

Mihesuah, Devon A

I998 Natives and Academics: Research and Writing about American Indians. Lincoln: University of Nebraska Press. 
Mihesuah, Devon A, and Angela C Wilson, editors 2004 Indigenizing the Academy: Transforming Scholarship and Empowering Communities. Lincoln: University of Nebraska Press.

Mills, Peter R

200I Speaking Up for Small Fish in the Big Pond: Establishing a Mission for the University of Hawaii at Hilo in Hawaiian Archaeology. In Pacific 2000: Proceedings of the Fifth International Conference on Easter Island and the Pacific, edited by Christopher M Stevenson, Georgia Lee, and F J Morin, I 5 I-I 55 . Los Osos, CA: Bearsville Press. NPS, National Park Service, US Department of the Interior

2010 Report on Hawaii State Historic Preservation Division Operations. I9 March.

Osorio, Jonathan K K

2002 Dismembering Lāhui: A History of the Hawaiian Nation to 1887. Honolulu: University of Hawai'i Press.

Said, Edward W

I978 Orientalism. New York: Vintage Books.

Silliman, Stephen W, editor

2008 Collaborating at the Trowel's Edge: Teaching and Learning in Indigenous Archaeology. Tucson: University of Arizona Press.

Silva, Noenoe K

2004 Aloha Betrayed: Native Hawaiian Resistance to American Colonialism. Durham, NC: Duke University Press.

Smith, Claire, and Gary Jackson

2006 Decolonizing Indigenous Archaeology: Developments from Down Under. American Indian Quarterly 30 (3/4): 3 I I-349.

Smith, Claire, and H Martin Wobst, editors

2005 Indigenous Archaeologies: Decolonizing Theory and Practice. One World Archaeology Series, volume 47. London: Routledge.

Smith, Linda Tuhiwai

I999 Decolonizing Methodologies: Research and Indigenous Peoples. Dunedin, NZ: University of Otago Press.

2005 On Tricky Ground: Researching the Native in the Age of Uncertainty. In The Sage Handbook of Qualitative Research, edited by Norman K Denzin and Yvonna S Lincoln, 85-I07. Third edition. Thousand Oaks, CA: Sage Publications.

Thomas, David Hurst

2000 Skull Wars: Kennewick Man, Archaeology, and the Battle for Native American Identity. New York: Basic Books.

Trask, Haunani-Kay

I999a From a Native Daughter: Colonialism and Sovereignty in Hawai i. Revised edition. Honolulu: University of Hawai'i Press. 
I999b What Do You Mean “We,” White Man? In From a Native Daughter: Colonialism and Sovereignty in Hawai ${ }^{\circ}$, I23-135. Honolulu: University of Hawai'i Press.

Watkins, Joe E

2000 Indigenous Archaeology: American Indian Values and Scientific Practice. Walnut Creek, cA: Alta Mira Press.

\section{Abstract}

Archaeology in Hawai'i has reached the century mark, and public perception of the discipline as a marginal esoteric pursuit has changed to one that associates the practice with land development and colonialism. The sociopolitical climate surrounding archaeology in the Hawaiian Islands is charged, and controversial events have contributed to present-day tensions. However, to understand these tensions we must go beyond anecdotes. This article presents narratives about the sociopolitical history of Hawaiian archaeology as conveyed in ethnographic interviews with Native Hawaiians and archaeologists. Themes brought forth in these narratives include discussion about the persistence of a living Hawaiian culture and the varying degrees of archaeological commitment to that culture. Ultimately an approach is sought that emphasizes Native Hawaiian people and culture and reframes archaeology in a supporting role. Through such reframing, issues of the practical application of archaeologically constructed knowledge for descendant communities are addressed, and the capacity of the discipline to advocate for Native Hawaiian communities is increased. Changing the current trajectory of historic preservation in Hawai'i to encompass a collaborative approach to cultural stewardship is necessary for the viability of the discipline as well as for the perpetuation of Hawaiian culture.

KEYWORDS: Hawai'i, indigenous archaeology, politics of the past, ethnography 